\title{
Presentation of the Howland Award to Horace Louis Hodes, M.D.
}

\author{
KURT HIRSCHHORN
}

Department of Pediatrics, Mt. Sinai School of Medicine, New York, New York, USA

\begin{abstract}
Dr. Hodes was born in Philadelphia on December 21, 1907. He received his elementary and high school education in Philadelphia and pursued one of his favorite activities by being a member of his high school baseball team. During his childhood he had a major experience which did much to lead to his determination to study medicine and particularly pediatrics. When he was six years old, two of his younger brothers contracted diphtheria. The diagnosis was not made for a number of days so that they did not receive antitoxin until the fifth day of illness, at which time they were taken to the only contagious disease ward in Philadelphia at the municipal hospital. They were intubated, survived for 25-30 days and then unfortunately died. By the time Dr. Hodes showed symptoms of diphtheria, the diagnosis on his brothers had been established and fortunately he received the antitoxin on the second day of his illness. Parenthetically, although diphtheria antitoxin had been developed by Von Behring in 1891, Dr. Bela Schick, Dr. Hodes' predecessor as Chairman of Pediatrics at Mount Sinai, did not do his work until 1913, just barely in time for Dr. Hodes' benefit. This combination of an enormous personal tragedy and his eventual recognition of the power of good medicine was a large determinant in Dr. Hodes' career goal.
\end{abstract}

At sixteen he entered the University of Pennsylvania where he received a full tuition competitive academic scholarship. At the tender age of 19 he began medical school at the University of Pennsylvania, again on full scholarship, won on the basis of a rigorous competitive examination. Although in retrospect this outcome could have been expected, it was also most fortunate, because financial considerations might well have prevented the medical profession from benefitting from Dr. Hodes' membership and activities. His college background in chemistry led him to begin a research project shortly after entering medical school. Together with another student, Milton Rappaport, he began to work actively on the newly discovered vitamin D. He was able to show that the action of vitamin $D$ was primarily to increase the absorption of calcium from the intestine rather than, as was thought at the time, by stimulation of the parathyroid glands. $\mathrm{He}$ disproved the then current dogma by producing tetany in dogs by removal of the thyroid and parathyroid glands and then curing the hypocalcemia and tetany by the administration of large doses of vitamin D. He also was able to demonstrate the toxic effect of vitamin $\mathrm{D}$ on the kidney. This work was published in two papers in the Journal of Biological Chemistry while Dr. Hodes was in his third year of medical school. This early research work instilled in Dr. Hodes a permanent deep involvement and joy in research, the results of which I will summarize later.

His broad clinical talents as a pediatrician were shaped during his tenure at the Children's Hospital of Philadelphia as intern, resident, and chief resident, between 1931 and 1935, interrupted by a year of residency at Johns Hopkins. To this day he remains the most respected clinician in our department. After his residency, he spent the first of many years on the faculty of Johns Hopkins, initially as the Director of the Dispensary of the Harriet Lane Home. Desirous of additional education, he then became an Assistant in Bacteriology at the Rockefeller Institute. This important period of rigorous training in basic research and in experi- mental epidemiology served him well in his life-long studies of clinical and experimental biology. After his return to Johns Hopkins as Director of the Sydenham Hospital in Baltimore, he again left for several years during the war when he became a Lieutenant Commander in the navy as a member of the Rockefeller Naval Research Unit and eventually as the officer in charge of the virus laboratory of the U.S. Naval Medical Research Unit in Guam. His four years in this Unit were highly fruitful in terms of concentrated and important research and profoundly influenced his continued commitment to experimental and clinical virology.

After his tenure in the Navy, Dr. Hodes returned to Johns Hopkins and for three more years was again the Director of Sydenham Hospital and was appointed as Associate Professor in the Department of Pediatrics. He also held an Associate Professorship in the Department of Preventive Medicine at the University of Maryland Medical School. He rapidly became recognized as the foremost teacher, clinician, and researcher in the rapidly growing field of virology and viral epidemiology. His clinical acumen in pediatric infectious diseases attracted many students who spread the good word around the country. His reputation came to the attention of the Mount Sinai Hospital in New York City and he was persuaded in 1949 to become the Chairman of Pediatrics at Mount Sinai, as the first fulltime Chairman in this first class teaching hospital. In this position he succeeded Drs. Abraham Jacobi, Henry Koplik, Bela Schick and Murray Bass, thereby maintaining a continuity of the highest excellence in that chair. At that time Mount Sinai was affiliated with Columbia University and Dr. Hodes was appointed as a Professor at that institution and became one of the most respected and desirable Attending Pediatricians at Babies Hospital. He quickly built the department at Mount Sinai into a first class training program for residents and fellows and produced a large number of graduates for faculties around the country. His own research continued to flourish and he and his colleagues continued to make fundamental contributions in infectious diseases and immunology. In the early 1960s the Trustees of Mount Sinai Hospital began to consider the development of a new medical school at Mount Sinai. As the first fulltime Chairman, Dr. Hodes had really set the academic tone that led toward this decision and then, together with a few other academicians recruited to Mount Sinai, developed the concepts and program of what has rapidly become a highly reputable and productive medical school: He remained Chairman of the Department until his retirement after 27 years in 1976 and in 1969 was awarded the newly endowed Herbert H. Lehman Professorship of Pediatrics. During his tenure as the Medical School Department Chairman, he successfully recruited an excellent faculty of fulltime pediatricians while wisely maintaining the active involvement of the superb voluntary clinical faculty who had made the Department great prior to that time.

Since his retirement as Chairman and appointment as a Distinguished Service Professor, brought about by questionable rules equating a person's talents with age rather than ability, he happily decided to stay on as an active member of the faculty. In this capacity he has continued to be the Chief of the Division of Infectious Diseases with no abatement of his clinical, teaching, 
and research activities in either quantity or quality. As a senior advisor to many in the school and the hospital, he continues to influence the continued growth of the Institution and will be rewarded this year with an honorary degree of Doctor of Science by Mount Sinai. Appropriately, he has also just been awarded the Jacobi Medal for Distinguished Service by the Alumni Association of Mount Sinai. He has been a member of and consultant to numerous governmental and private health agencies and commissions. In 1975, he was honored by publication of a unique full issue Festschrift in the Journal of Pediatrics, edited by his late friend Alex Steigman, and containing a beautiful, warm and personal appreciation of Horace by Helen Taussig.

Among his many fundamental contributions in research, time permits me to mention only a few of the highlights.

In 1936, before the basic structure of viruses was known, Dr. Hodes reasoned that the application of a carefully controlled physical force to a virus might destroy its infectiousness while leaving its immunizing capacity unchanged. He therefore exposed tissue culture grown rabies virus to a measured dose of ultraviolet light that made the virus completely non-infectious for animals, but left its immunizing properties intact. This ultraviolet method was used commercially for some years to make non-infectious rabies and influenza virus vaccines. Many years later it was shown that a small dose of ultraviolet light causes an alteration of the base pairs of the nucleic acid of a virus and renders it noninfectious. This treatment leaves the protein coat of the virus relatively unchanged and still able to elicit an immune response.

In Baltimore in 1942, Drs. Hodes and J. S. Light isolated a filterable virus from four hospital outbreaks of infantile diarrhea. This virus caused diarrhea in calves. Hodes and Light published clear laboratory and epidemiologic evidence that the virus was the cause of the infants' diarrhea. This work was published in brief in 1943, and in great detail in The Journal of Experimental Medicine in 1949. It was the first demonstration of a viral etiology of gastroenteritis. Subsequent events have made it quite clear that the virus isolated in 1942 is the human rotavirus. Samples of the Baltimore virus which Dr. Hodes had lyophilized in 1942, were examined in 1974 by electron microscopy. The 1942 virus was found to have the same size and morphology as the human rotavirus found in Australia in 1973, and the 1942 virus was found by serologic methods to be the same as the 1973 rotavirus. It is now known that rotavirus is the most common cause of gastroenteritis in infants and children.

Dr. Hodes began studies on the vaccination of children against pneumococci in the early 1940s. He showed that a heat-killed vaccine that he prepared induced an excellent antibody response in children who were more than two years old, and he was probably the first to show that children under two were unable to produce antibody after vaccination with pneumococci.

Dr. Hodes devised a paper radioimmunoassay method that enabled him to show that serum contains at least two kinds of antipoliovirus antibodies with different physical properties. $\mathrm{He}$ also showed that the major polio antibody in human milk is different from the major polio antibody in serum. This work was an important step in the identification of $\operatorname{IgA}$ and secretory $\operatorname{IgA}$. It was described in a number of papers published between 1957 and 1966. Incidentally, for many years, Dr. Hodes was actively involved in improving the treatment of polio victims, and, at Mount Sinai, headed one of the largest centers for this purpose.

Another example of Dr. Hodes' research in virology is illustrated by his clarification of the epidemiology of Japanese encephalitis. It was known that adult mosquitoes directly transmitted the virus from the blood of one bird or animal to another. Dr. Hodes showed that mosquitoes could be infected by the virus in their larval stage, and that the virus would survive and multiply in their tissues. He showed that when such mosquitoes emerged as adults their bite could cause encephalitis in animals. This was the first demonstration of this kind of virus transmission by mosquitoes and led to new approaches for mosquito control for the protection of our troops in World War II.
In 1942, Rake, Schaffer, and Hodes isolated measles virus from the brain of a child who died of measles encephalitis. This was accomplished by inoculation into monkeys of a concentrated suspension of whole brain cells. This was the first successful isolation of measles virus from the brain. Dr. Purnell Choppin has recently stated that the demonstration that measles virus could be recovered from the brain cells of a child with measles encephalitis by injection of these intact cells into monkeys can now be appreciated as an experiment that foreshadowed the technique of cocultivation, a technique used to great advantage in the study of subacute sclerosing panencephalitis (SSPE). Viewed in this light, the experiments of Dr. Hodes and his colleagues are an indication that measles encephalitis (like SSPE) is caused by a defective virus. The virus may be defective in the production of $M$ protein which stabilizes the virus envelope and organizes the process of budding.

The last scientific work that I shall cite is Dr. Hodes' discovery of the elution marker ("E" marker) that distinguishes attenuated vaccine poliovirus from wild type poliovirus. The attenuated strain is firmly absorbed by DEAE cellulose resin, and cannot be eluted from it, whereas the wild virus is not bound by the resin.

One of Dr. Hodes' most beautiful characteristics is his ability to interact on a warm and personal level with his colleagues. Early in his development this led to a close relationship with those who influenced his career. First among these was Dr. Edwards A. Park, the former Chairman of Pediatrics at Johns Hopkins. He was probably the most important early influence in Dr. Hodes' life. Dr. Park's unselfish honesty and the great pleasure he derived from the success of his pupils represented a magnificent role model which allowed Dr. Hodes to manifest his own natural talents of clinical and scientific excellence and his innate ability to support and encourage young physicians. It is of interest that Dr. Park was the first winner of the Howland Award 30 years ago in 1952. The other major influence on his early career was Dr. Joseph Stokes who chose Dr. Hodes to present the Howland Award to him 20 years ago. Dr. Stokes warmly and strongly supported research by his students and always looked out for their interest, a quality which Dr. Hodes has maintained. Another trait shared by Drs. Stokes and Hodes is their absolute intolerance of injustice and racial, religious, or sex bias. They have always been willing to pay whatever price was required to speak out and act against any evidence of such injustice.

Of all the people who have assisted and inspired Dr. Hodes, the foremost has been Helen Zepp, known affectionately to everyone as Zeppy. He first met Zeppy when he was a houseofficer at Hopkins in 1933. At that time she was in charge of the bacteriologic work that was carried out in the Harriet Lane Home then and for many years thereafter. She worked in a small basement laboratory which was, of course, not air-conditioned and, in the Baltimore climate with Bunsen burners and autoclaves going it was much hotter than any African jungle. Zeppy taught him that there was only one right way to carry out any technique. Everything that she did was done with precision and accuracy and nothing was left to chance. In planning an experiment he soon learned that if he could convince Zeppy that they were on the right track that everything would work well. Many times, however, she pointed out flaws in his thinking and planning that saved endless and useless work and expense. She has been a full partner in much of the work that he has carried out. In addition, she has been a very close friend to him and to his wife Anne and their children and grandchildren.

While on the subject of his family, one cannot speak about Dr. Hodes without emphasizing the enormous warmth and reciprocal support between him and his marvelous wife Anne. They will be married 51 years this June and still behave as if it had just happened. Anne, working as a teacher, supported Horace during his years as a houseofficer, because in those days interns and residents were not paid at all. It was not until after Horace finished his training and his work at the Rockefeller Institute, when they had been married for eight years, that they felt secure enough to 
start a family. Since then his wife, his two marvelous children, David and Ruth, and more recently, his grandchildren have always represented his first priority. It is most fitting that his talented son will soon become the Chief of the Division of Pediatric Infectious Diseases at Mount Sinai, the position Dr. Hodes has held with enormous success since his so-called retirement in 1976. At work in the laboratory and on the floors every day, Horace has continued to be the most respected teacher and clinician in the department and has continued to do creative research, most recently on the phenomenon of bacterial tolerance. I and the staff, of course, expect him to continue working forever.

A word should be said about the staff. In a time of increasing difficulties between the fulltime and the voluntary components of faculties, there has never been such a split in Dr. Hodes's department. He appreciated and encouraged all forms of talent, as long as they continued to shoulder their responsibilities. They have all participated on a daily basis in the philosophy and activities of the most democratically run department I have ever seen.

Aside from the vast amount of time devoted to his work and both his families at home and at Mount Sinai, Dr. Hodes has always actively participated in outdoor sports. His early talents culminated in his becoming a semi-professional baseball player, while more recently his major outside activity has been fishing.
He derives great pleasure from a peaceful period on a boat to collect his thoughts and invariably to land some big specimens.

When I nominated Dr. Hodes for the Howland Award I was overwhelmed by the enormous support for this nomination by so many of the greats of American Pediatrics today. The letters are magnificent in their praise and I would only like to quote one of these, from Joe St. Geme, because it says it all so beautifully. He writes and I quote: "This is a joy because Horace Hodes is a magnificent human being and, in my view, the most illustrious, complete academic pediatrician in our nation. His accomplishments as a clinician, educator, teacher, scientist and leader are unparalleled ... At a time in our history when the artificiality of the media obscures quality and humanity, it would be so refreshing if one's peers might recognize the excellence of a quiet, humble, sincere scholar with their greatest accolade."

As for me, I first met Horace in the early 1960s when he asked me to consult on a child with a chromosomal defect. For me it was love at first sight. It has been an affair that has never ceased to give me joy and that has been a constant challenge to maintain the high standards set by Horace. It gives me the greatest personal pleasure to present Horace Louis Hodes for the Howland Award of The American Pediatrics Society. 